\title{
Trophoblast stem cell marker gene expression in inner cell mass-derived cells from parthenogenetic equine embryos
}

\author{
Joëlle A Desmarais ${ }^{1}$, Simon-Pierre Demers ${ }^{1}$, Joao Suzuki Jr ${ }^{1}$, Simon Laflamme ${ }^{1}$, Patrick Vincent ${ }^{1}$, \\ Sheila Laverty ${ }^{2}$ and Lawrence C Smith ${ }^{1}$ \\ ${ }^{1}$ Department of Veterinary Biomedicine, Faculty of Veterinary Medicine, Centre de Recherche en Reproduction \\ Animale and ${ }^{2}$ Department of Clinical Sciences, Faculty of Veterinary Medicine, University of Montreal, 3200 Sicotte, \\ St-Hyacinthe, Quebec J2S 7C6, Canada \\ Correspondence should be addressed to L C Smith; Email: lawrence.c.smith@umontreal.ca
}

\begin{abstract}
Although putative horse embryonic stem (ES)-like cell lines have been obtained recently from in vivo-derived embryos, it is currently not known whether it is possible to obtain ES cell (ESC) lines from somatic cell nuclear transfer (SCNT) and parthenogenetic (PA) embryos. Our aim is to establish culture conditions for the derivation of autologous ESC lines for cell therapy studies in an equine model. Our results indicate that both the use of early-stage blastocysts with a clearly visible inner cell mass (ICM) and the use of pronase to dissect the ICM allow the derivation of a higher proportion of primary ICM outgrowths from PA and SCNT embryos. Primary ICM outgrowths express the molecular markers of pluripotency POU class 5 homeobox 1 (POU5F1) and (sex determining region-Y)-box2 (SOX2), and in some cases, NANOG. Cells obtained after the passages of PA primary ICM outgrowths display alkaline phosphatase (AP) activity and POU5F1, SOX2, caudal-related homeobox-2 (CDX2) and eomesodermin (EOMES) expression, but may lose NANOG. Cystic embryoid body-like structures expressing POU5F1, CDX2 and EOMES were produced from these cells. Immunohistochemical analysis of equine embryos reveals the presence of POU5F1 in trophectoderm, primitive endoderm and ICM. These results suggest that cells obtained after passages of primary ICM outgrowths are positive for trophoblast stem cell markers while expressing POU5F1 and displaying AP activity. Therefore, these cells most likely represent trophoblast cells rather than true ESCs. This study represents an important first step towards the production of autologous equine ESCs for pre-clinical cell therapy studies on large animal models.
\end{abstract}

Reproduction (2011) 141 321-332

\section{Introduction}

Embryonic stem cells (ESCs) are derived from the inner cell mass (ICM) of the blastocyst and are pluripotent, i.e. have the capacity to contribute to all three germ layers, including the germline. Isolation, expansion and differentiation of ESCs in vitro are technologies that can lead to the use of ESCs in therapeutic treatments, thus raising hopes for new protocols for treating previously incurable diseases such as arthritis and Parkinson's disease. Immunocompatible ESCs that could be tolerated by the immune system would alleviate the need for administration of immunosuppressor drugs to the host following therapy. Immunocompatible ESCs can be generated using somatic cell nuclear transfer (SCNT) to introduce a somatic cell nucleus into an enucleated oocyte (Hochedlinger \& Jaenisch 2003). Cells from embryos generated by SCNT are genetically identical to the donor cell, except for the mitochondrial DNA, which can be inherited from the recipient oocyte. Histocompatibility of SCNT-derived tissues and cells was nevertheless demonstrated in studies using bovine species (Lanza et al. 2002, Theoret et al. 2006). Alternatively, fully major histocompatibility complex (MHC)-matched ESCs can be derived from parthenogenetic (PA) embryos, if they are heterozygous for MHC loci (Kim et al. 2007a). PA embryos develop from an unfertilised oocyte that is rendered diploid either naturally or experimentally (Balakier \& Tarkowski 1976).

ESC lines from PA embryos have been derived from mouse, non-human primate and human species (Kaufman et al. 1983, Allen et al. 1994, Cibelli et al. 2002, Lin et al. 2003, Kim et al. 2007 b). Such ESC lines have also been derived from mouse SCNT embryos (Kawase et al. 2000, Munsie et al. 2000, Wakayama et al. 2001). Derivation of putative ESC lines from bovine NT embryos was also reported (Cibelli et al. 1998, Wang et al. 2005), but not from equine PA nor from SCNT embryos. Recent evidence suggests that SCNT-derived ESCs are functionally equivalent to IVF-derived ESCs and have the same differentiation potential (Surani \& Barton 1983, Allen et al. 1994, Munsie et al. 2000, 
Wakayama et al. 2001, 2006, Hochedlinger \& Jaenisch 2002, Rideout et al. 2002, Lin et al. 2003, Brambrink et al. 2006, Kim et al. 2007 b).

The horse is an economically important domestic species. ESCs are needed in horses to provide an abundant and high-quality source of cells for use in stem cell-based therapies and to develop these therapies for human disease.

Putative ESC lines have been derived from farm animals including cows (Evans et al. 1990, Sims \& First 1994, Cibelli et al. 1998, Iwasaki et al. 2000, Mitalipova et al. 2001, Saito et al. 2003, Wang et al. 2005), pig (Notarianni et al. 1990, Piedrahita et al. 1990, Hochereau-de Reviers \& Perreau 1993, Wheeler 1994, Chen et al. 1999, Li et al. 2003, 2004a, 2004b) and horses (Saito et al. 2002, Li et al. 2006). However, few have demonstrated pluripotency in vivo, and none have contributed to the germline. ESC derivation protocols and culture conditions need to be optimised in species other than mice, non-human primates and humans. In the horse, it is currently not known whether it is possible to obtain autologous ESC lines from SCNT and PA embryos. In this study, we examine different protocols to obtain primary equine ICM outgrowths from PA and SCNT embryos and evaluate the expression and significance of different pluripotency-associated markers for the characterisation of equine cells derived from primary ICM outgrowths.

\section{Results}

\section{Conditions affecting the derivation of primary equine ICM outgrowths from in vivo, PA and SCNT embryos}

Upon plating, isolated ICM cells grew either as a flattened sheet of morphologically differentiated cells or as a domed mound - or primary ICM outgrowth sitting on the flattened sheet of cells. Different culture conditions were tested to derive primary ICM outgrowths from in vivo (Fig. 1A), PA (Fig. 1B) and SCNT (Fig. 1C) blastocysts. Table 1 shows the proportion of primary ICM outgrowths obtained, in relation to embryo origin. Although high derivation efficiency was found in all three groups $(66 \%$ for in vivo, $48 \%$ for PA and SCNT embryos), the efficiency was significantly lower when using PA compared with in vivo embryos (Table 1). This suggests that origin of the embryo influences derivation of primary ICM outgrowths.

Feeder cells from different origins were used and compared to evaluate the influence of feeder cells on the derivation of primary ICM outgrowths in each experimental group. Bovine umbilical cord fibroblast (BUCF), equine umbilical cord fibroblast (EUCF) and equine embryonic fibroblast (EEF) cell lines were generated and used $24-48 \mathrm{~h}$ after mitotic inactivation for derivation. No significant difference was found in the derivation efficiency with any of the feeder cells used, for any of the groups (in vivo, PA or SCNT),
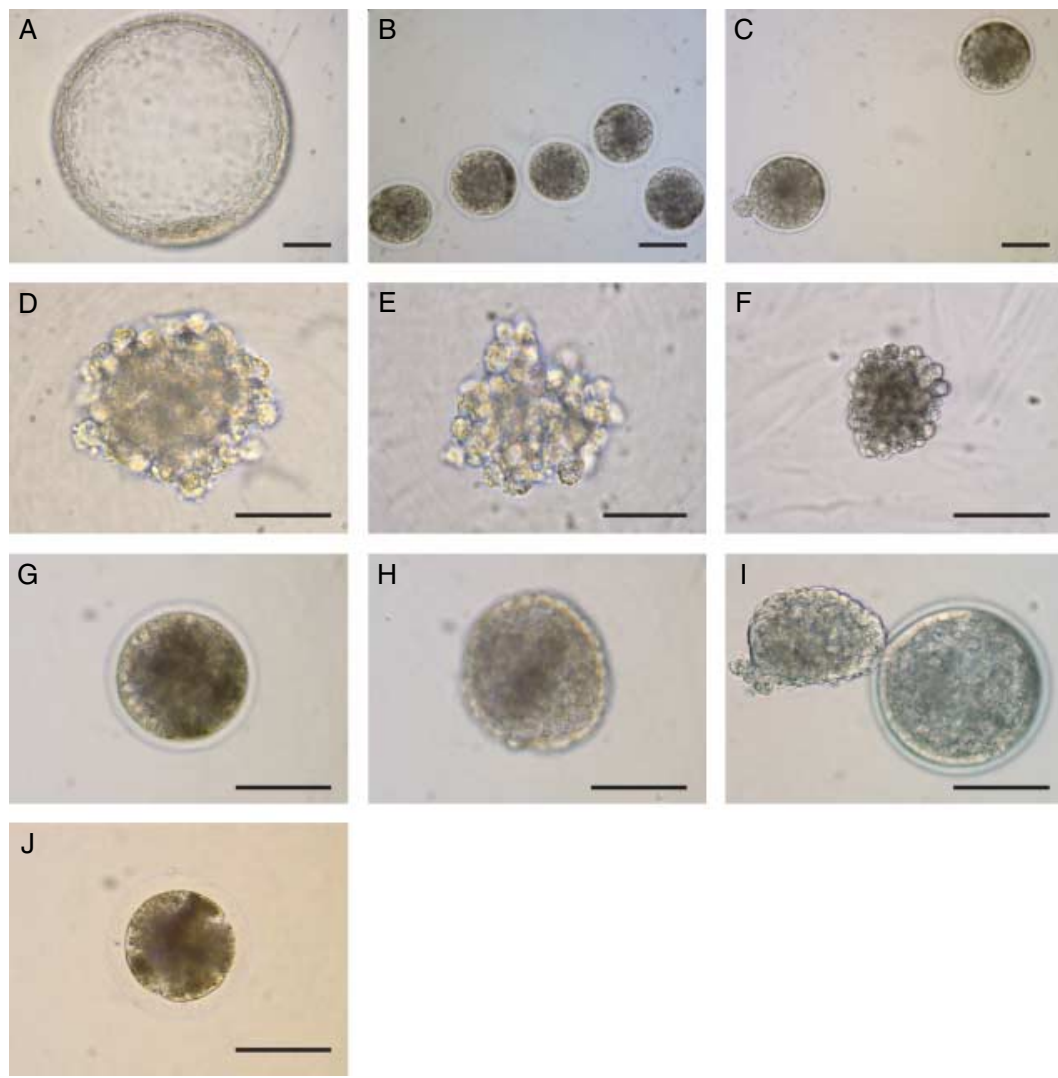
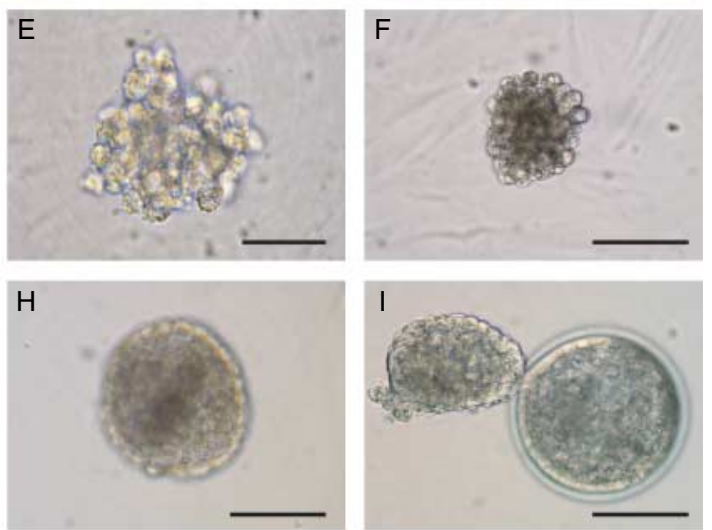

Figure 1 Characteristics of in vivo, PA and SCNT equine embryos. Morphology of $7.0 \mathrm{dpc}$ in vivo blastocyst (A), 7.0 days post-activation PA blastocyst (B) and SCNT blastocyst (C). Isolated ICM from in vivo (D) and PA (E) blastocysts dissected with trypsin, and ICM from a PA blastocyst dissected with pronase (F). An early PA blastocyst (G), an earlyexpanded PA blastocyst without its zona pellucida $(\mathrm{H})$ and a hatching PA blastocyst (I). A PA embryo without a detectable ICM (J). Bars $=100 \mu \mathrm{m}$. 
Table 1 Total number of primary equine inner cell mass (ICM) outgrowths is influenced by blastocyst origin.

\begin{tabular}{lcc}
\hline $\begin{array}{l}\text { Blastocyst } \\
\text { origin }\end{array}$ & $\begin{array}{c}\text { Number of } \\
\text { attached } \\
\text { blastocysts }\end{array}$ & $\begin{array}{c}\text { Number of primary ICM } \\
\text { outgrowths/number of } \\
\text { attached blastocysts }(\%)\end{array}$ \\
\hline In vivo & 38 & $25(66 \%)^{\mathrm{a}}$ \\
PA & 172 & $82(48 \%)^{\mathrm{b}}$ \\
SCNT & 27 & $13(48 \%)^{\mathrm{ab}}$ \\
\hline
\end{tabular}

${ }^{a, b}$ Values with different superscripts in the same column are significantly different $(P=0.04)$.

suggesting that the origin of the feeder cells is not a primary factor to consider when deriving primary ICM outgrowths (Table 2).

To isolate the ICM, equine embryos were treated enzymatically either with trypsin (Fig. 1D and E) or with pronase (Fig. 1F). Pronase was found to be ineffective for the dissociation of trophoblast cells from in vivo embryos, while trypsin dispersed trophoblast cells effectively, allowing ICM isolation. In the in vivo group, $72 \%$ of the ICMs isolated with trypsin yielded primary ICM outgrowths (Table 3). Both trypsin and pronase were used with PA and SCNT embryos. Although a higher ratio of primary ICM outgrowths was obtained with pronase $(41 \%$ for PA and $47 \%$ for SCNT groups), there was no significant difference with respect to the enzyme used to isolate the ICM (Table 3).

Embryos from in vivo, PA and SCNT groups were classified according to their age and developmental stage before they were used for derivation of primary ICM outgrowths. In vivo embryos aged between 6.0 and 9.5 days post-coitum (dpc) were used, and no statistical difference was found regarding the efficiency of primary ICM outgrowth formation. Similarly, PA and SCNT embryos aged between 6.0 and over 10.0 days postactivation were used. It was found that in these groups, formation of primary ICM outgrowth was significantly less efficient when using older embryos (10.0 days postactivation and over), compared with the use of embryos aged between 6.0 and 9.5 days post-activation (Table 4). Likewise, no difference was observed in in vivo embryos from different developmental stages, whereas PA and SCNT late blastocysts, including late-expanded, hatching (Fig. 1I) and hatched blastocysts, gave a significantly lower number of primary ICM outgrowths compared with early (Fig. 1G) and early-expanded (Fig. 1H) blastocysts (Table 5).

The parameter of ICM identification in PA and SCNT embryos was evaluated to detect possible influence on the derivation of primary ICM outgrowths. Blastocysts with a detectable ICM and those with a non-detectable ICM (Fig. 1J) were classified, and their ability to form a primary ICM outgrowth was evaluated. PA and SCNT blastocysts presenting a clearly visible ICM were more prone to develop into a primary ICM outgrowth than embryos that were not showing a clearly identifiable
ICM (Table 6). Together, these results suggest that prior morphological evaluation of embryos is beneficial for the improvement of derivation efficiency of primary ICM outgrowths from PA and SCNT embryos.

\section{Morphological and molecular evaluation of primary equine ICM outgrowths}

Between 1 and 5 days post-plating, primary ICM outgrowths formed in culture. Differences were observed between primary outgrowths from in vivo, PA and SCNT blastocysts. In the in vivo group, primary ICM outgrowths emerged on a sheet of flattened cells (Fig. 2A and $\mathrm{B}$ ). These outgrowths consisted of a rounded mass composed of tightly compacted cells, where individual cells were not discernable (Fig. 2A). After a few days in culture, a layer of cells displaying a different morphology formed as an outer layer around the tightly compacted cell mass (Fig. 2B). When isolated and plated onto a new feeder layer for 2-3 days, the ICM outgrowth-derived cells appeared to have readily undergone morphological differentiation into a flattened sheet of cells. In contrast, tightly compacted cells of the ICM outgrowths from PA and SCNT embryos were surrounded by cells that had a darker and a more rounded and dispersed appearance than the cells composing the outer layer of in vivo ICM outgrowths (Fig. 2C-F). Notably, in two cases, primary ICM outgrowths from PA embryos displayed a similar morphology to that observed with in vivo embryos.

Cells composing the primary ICM explant - the primary ICM outgrowth together with the flattened sheet of cells - were characterised by analysing marker gene expression by reverse transcriptase-PCR (RT-PCR; Fig. 3). POU class 5 homeobox 1 (POU5F1) and (sex determining region-Y)-box2 (SOX2) transcripts were expressed in $7 / 8$ and $6 / 8$ ICM explants respectively. Notably, SOX2 expression was weaker in one in vivo ICM explant. NANOG was clearly expressed in three ICM explants analysed, from SCNT and in vivo explants groups only. Trophoblast stem (TS) cell marker genes caudal-related homeobox-2 (CDX2) and eomesodermin (EOMES) were expressed in 6/8 and 8/8 ICM explants respectively, with representatives in all groups. These results suggest that the ICM explants derived from in vivo, PA and SCNT embryos may display pluripotency as well as TS cell marker genes expression, as shown by RT-PCR.

Table 2 The relative number of primary equine inner cell mass (ICM) outgrowths is not influenced by the feeder cells used.

\begin{tabular}{|c|c|c|c|}
\hline \multirow[b]{2}{*}{$\begin{array}{l}\text { Feeder } \\
\text { layer }\end{array}$} & \multicolumn{3}{|c|}{ Number of primary ICM outgrowths } \\
\hline & $\begin{array}{c}\text { In vivo } \\
\text { blastocysts (\%) }\end{array}$ & $\begin{array}{c}\text { PA } \\
\text { blastocysts (\%) }\end{array}$ & $\begin{array}{c}\text { SCNT } \\
\text { blastocysts (\%) }\end{array}$ \\
\hline EEF & $6 / 10(60 \%)$ & $51 / 111(46 \%)$ & 4/11 (36\%) \\
\hline EUCF & $14 / 20(70 \%)$ & 16/32 (50\%) & 9/13 (69\%) \\
\hline BUCF & $5 / 6(83 \%)$ & $14 / 26(54 \%)$ & $\mathrm{N} / \mathrm{A}$ \\
\hline
\end{tabular}

N/A, not analysed. 
Table 3 Relative number of primary equine inner cell mass (ICM) outgrowths is not influenced by the method of ICM isolation.

\begin{tabular}{llrr}
\hline & \multicolumn{3}{c}{ Number of primary ICM outgrowths } \\
\cline { 2 - 4 } Method of & \multicolumn{1}{c}{ In vivo } & \multicolumn{1}{c}{ PA } & \multicolumn{1}{c}{ SCNT } \\
ICM isolation & blastocysts (\%) & blastocysts (\%) & blastocysts (\%) \\
\hline Trypsin & 23/32 $(72 \%)^{\mathrm{a}}$ & $20 / 52(38 \%)^{\mathrm{b}}$ & $2 / 9(22 \%)^{\mathrm{b}}$ \\
Pronase & N/A & $54 / 131(41 \%)^{\mathrm{b}}$ & $9 / 19(47 \%)^{\mathrm{b}}$
\end{tabular}

a,b Values with different superscripts in the same row are significantly different $(P=0.006)$.

\section{Morphological, molecular and biochemical evaluation of equine ES-like cells obtained after passages of PA primary ICM outgrowths}

The cells obtained after the first passage of PA primary ICM outgrowths displayed morphological characteristics of ESCs (Fig. 4). Individual cells showed a high nucleus to cytoplasm ratio, and colonies had defined borders (Fig. 4A and B). Compact colonies of densely packed cells were observed 1 day after passage (Fig. 4C). After 5 days in culture, colonies became flattened, and two characteristic morphologies were observed; either a monolayer of cells with dispersed structures composed of tightly packed cells (Fig. 4D) or flattened colonies with a defined border (Fig. 4E). As shown in Fig. 4F and G, colonies were still displaying alkaline phosphatase (AP) activity after five passages. Cells were cultured in suspension for 7 days without leukaemia inhibitory factor (LIF) or feeder cells to obtain cystic embryoid body (EB)-like structures (Fig. 4H).

The pluripotent identity of PA cells obtained after passages of primary ICM outgrowths was assessed by RT-PCR to evaluate marker gene expression (Fig. 5). POU5F1 was expressed in all cells derived from three distinct primary ICM outgrowths. SOX2 was expressed in two out of three groups, and NANOG was either expressed at very low levels or could not be detected. On the other hand, CDX2 and EOMES were present in all cells derived from primary ICM outgrowths. These results suggest that the cells obtained show expression of markers by RT-PCR of both mouse pluripotent ES and TS cells, although NANOG is not clearly expressed in these cells. The cystic EB-like structures, produced by culturing the PA cells obtained after passaging ICM outgrowths in suspension without LIF or feeder cells, expressed POU5F1, CDX2 and EOMES, but the expression of both SOX2 and NANOG was absent, suggesting that the EB-like structures were composed of TS cells.

\section{POU5F1 and GATA6 expression in in vivo, PA and SCNT equine embryos}

The expression and localisation of POU5F1 and GATAbinding protein-6 (GATA6), markers of pluripotent cells and of primitive endoderm (PE) respectively, were examined by immunofluorescence and confocal microscopy. A POU5F1 antibody detecting specifically the isoform associated with pluripotency (POU5F1A) was used. In in vivo embryos (Fig. 6A), POU5F1 was expressed in trophectoderm (TE), PE and ICM cells of the blastocyst at $7.0 \mathrm{dpc}$, whereas GATA6 was restricted to PE cells. In 6.0 days post-activation PA embryos (Fig. 6B), both POU5F1 and GATA6 were expressed distinctly in TE and ICM cells. In 8.0 days post-activation PA nonexpanded (Fig. 6C) or expanded blastocysts (Fig. 6D) and in 7.5 days post-activation SCNT blastocysts (Fig. 6E), POU5F1 and GATA6 were expressed in both TE and PE cells, whereas a few ICM cells expressed exclusively POU5F1, and not GATA6. Together, these results suggest that POU5F1 is not restricted to the ICM in the equine embryo, as it also localised to the extraembryonic compartments of TE and PE.

\section{Discussion}

This study compares the efficiency of primary ICM outgrowth derivation from equine in vivo, PA and SCNT embryos. To our knowledge, this is the first report of in vitro proliferation of cells derived from primary ICM outgrowths from in vivo, PA and SCNT equine embryos positive for APactivity, as well as for POU 5F1 and SOX2 expression. The impact of different derivation parameters on growth of primary ICM outgrowths was compared. Furthermore, this study characterises the expression of POU5F1 and GATA6 proteins in in vivo, PA and SCNT equine blastocysts, and shows the expression of POU5F1 in the ICM as well as in the TE and the PE. POU5F1, CDX2 and EOMES expression was also demonstrated in AP-positive cells derived from PA primary ICM outgrowths.

PA and SCNT embryos may have placentation defects, and this has been attributed to abnormal imprinting of paternally expressed genes (Surani \& Barton 1983, Ohgane et al. 2001, Singh et al. 2004). However, similarity of transcriptional profiles of ESC lines derived from in vitro fertilised and SCNT mouse embryos suggests that these embryos are suitable for production of functional ESC lines (Brambrink et al. 2006,

Table 4 Relative number of primary equine inner cell mass (ICM) outgrowths is influenced by the age of the blastocyst.

\begin{tabular}{llcc}
\hline & \multicolumn{3}{c}{ Number of primary ICM outgrowths } \\
\cline { 2 - 4 } $\begin{array}{l}\text { Age of } \\
\text { blastocyst (days*) }\end{array}$ & \multicolumn{1}{c}{ In vivo } & \multicolumn{1}{c}{ PA } & SCNT \\
\hline $6.0-7.5$ & $16 / 23(70 \%)$ & $59 / 108(55 \%)^{\mathrm{a}}$ & $6 / 8(75 \%)^{\mathrm{a}}$ \\
$8.0-9.5$ & $9 / 15(60 \%)$ & $16 / 40(40 \%)^{\mathrm{ab}}$ & $4 / 6(67 \%)^{\mathrm{ab}}$ \\
10.0 and over & N/A & $7 / 24(29 \%)^{\mathrm{b}}$ & $3 / 13(23 \%)^{\mathrm{b}}$ \\
\hline
\end{tabular}

${ }^{a, b}$ Values with different superscripts in the same column varies significantly $(P=0.02)$.

*Days post-coitum for in vivo, days post-activation for PA and SCNT blastocysts. 
Table 5 Relative number of primary equine inner cell mass (ICM) outgrowths depends on the developmental stage of the blastocyst.

\begin{tabular}{|c|c|c|c|}
\hline \multirow[b]{2}{*}{$\begin{array}{l}\text { Developmental } \\
\text { stage }\end{array}$} & \multicolumn{3}{|c|}{ Number of primary ICM outgrowths } \\
\hline & $\begin{array}{c}\text { In vivo } \\
\text { blastocysts (\%) }\end{array}$ & $\begin{array}{c}\text { PA } \\
\text { blastocysts (\%) }\end{array}$ & $\begin{array}{c}\text { SCNT } \\
\text { blastocysts (\%) }\end{array}$ \\
\hline Early blastocyst & 9/10 (90\%) & $49 / 99(49 \%)^{\mathrm{a}}$ & $5 / 7(71 \%)^{\mathrm{a}}$ \\
\hline $\begin{array}{l}\text { Expanded } \\
\text { blastocyst }\end{array}$ & $13 / 22(59 \%)$ & $19 / 34(56 \%)^{a}$ & $4 / 6(67 \%)^{a b}$ \\
\hline Late blastocyst* & $3 / 6(50 \%)$ & $2 / 14(14 \%)^{b}$ & $4 / 14(29 \%)^{b}$ \\
\hline
\end{tabular}

${ }^{\mathrm{a}, \mathrm{b}}$ Values with different superscripts in the same column are significantly different ( $P=0.008$ for PA and $P=0.05$ for SCNT).

*Includes late, expanded blastocysts, hatching and hatched blastocysts.

Wakayama et al. 2006). Moreover, studies in the mouse suggest that SCNT and PA ESC lines have the same differentiation potential as IVF- or in vivo-derived ESC lines (Surani \& Barton 1983, Allen et al. 1994, Munsie et al. 2000, Wakayama et al. 2001, 2006, Hochedlinger \& Jaenisch 2002, Rideout et al. 2002, Lin et al. 2003, Kim et al. 2007a). In the present investigation, almost half of the embryos from the PA and SCNT groups yielded primary ICM outgrowths, which indicates high derivation efficiency. These data support that PA and SCNT embryos give rise efficiently to primary ICM outgrowths, despite the likelihood of abnormal placentation later on in development. However, our data suggest that the in vivo embryos give a statistically higher number of primary ICM outgrowths, indicating a possible difference in the phenotype of in vitro and in vivo grown ICMs from blastocysts.

In previous reports describing the derivation of putative ESC lines from horse embryos, immunosurgery (Li et al. 2006) and microsurgery (Saito et al. 2002) were used to isolate the ICM. In the rabbit, immunosurgery was found to be less effective than trypsin digestion of PA embryos, as immunosurgery leaves extraembryonic tissues attached to the ICM (Wang et al. 2007). In accordance with these data, immunosurgery of in vivo bovine embryos was shown to leave the PE and sometimes the TE cells attached to the ICM (Talbot et al. 1995, 2005). Therefore, we did not make use of immunosurgery to isolate the ICM from in vivo embryos in this study. In preliminary attempts, mechanical isolation of the ICM with a scalpel blade did not allow a complete removal of extraembryonic tissue, while plating of the whole embryo did not allow attachment within $48 \mathrm{~h}$ of culture in most cases (data not shown) in this study. Enzymatic isolation of ICM was found to be the most effective for ICM isolation from PA and NT embryos and allowed rapid attachment of the ICM to the feeder layer within $24 \mathrm{~h}$.

Earlier attempts to maintain equine ESCs in culture have made use of BUCFs (Saito et al. 2002), mouse embryonic fibroblasts and EEFs (Li et al. 2006), but no study has yet compared the effect of using feeders from different sources on the derivation of primary ICM outgrowths. In this study, we have derived and compared the potential of feeder cells of different sources - BUCFs, EUCFs and EEFs - for the derivation of primary ICM outgrowths. No significant differences were observed when using different feeders. Similarly, Li et al. (2006) reported no difference between feeders from mouse or equine origins for culture and maintenance in undifferentiated state of established putative equine ESCs. The use of EEFs would be preferable as they are homologous, secrete species-specific hormones and factors, and prevent cross-species contamination and transmission of xenopathogens. Nevertheless, all the feeders used in this study failed to maintain NANOG-positive ESCs after passaging. In our experience, the absence of LIF was not detrimental to the maintenance of POU5F1 and AP-positive cells after passaging of PA primary ICM outgrowth, although the absence of feeders was detrimental (data not shown). This dependence on feeder cells, but not on LIF, is consistent with the data reported by Saito et al. (2002), but in contradiction with $\mathrm{Li}$ et al. (2006), who observed that both LIF and feeder cells were required for the maintenance of undifferentiated ES-like cell state, although all three studies made the use of human recombinant LIF at a concentration ranging from 10 to $40 \mathrm{ng} / \mathrm{ml}$. The significance of LIF in the maintenance of the undifferentiated state of equine ESCs merits further investigation.

Embryos at different developmental stages were used to assess primary ICM outgrowth formation. In this study, a larger proportion of primary ICM outgrowths was obtained if early-stage blastocysts were used, in comparison with late-stage blastocysts. This could be explained by the prolonged length of exposure time to in vitro culture, which may be detrimental to the viability and integrity of the blastocysts. Bovine in vivo embryos from 16-cell stage to hatched blastocyst aged 10-11 dpc are believed to be the most permissive stages for bovine ES-like cell derivation (Sims \& First 1994, Strelchenko 1996, Cibelli et al. 1998, Iwasaki et al. 2000). Our results suggest that, for equine in vitro embryos produced by parthenogenesis or cloning, early blastocysts aged $<9.5$ days post-activation should be the permissive condition for the derivation of primary ICM outgrowths. Whether the use of earlier stage embryos would have resulted in a better outcome is not known, but according to experiments carried out with bovine embryos, little

Table 6 Relative number of primary equine inner cell mass (ICM) outgrowths depends on ICM identification prior to isolation.

\begin{tabular}{lcc}
\hline \multirow{2}{*}{ ICM identification } & \multicolumn{2}{c}{ Number of primary ICM outgrowths } \\
\cline { 2 - 3 } & PA blastocysts $(\%)$ & SCNT blastocysts $(\%)$ \\
\hline Detectable & $61 / 117(52 \%)^{\mathrm{a}}$ & $11 / 16(69 \%)^{\mathrm{a}}$ \\
Not detectable & $12 / 37(32 \%)^{\mathrm{b}}$ & $2 / 11(18 \%)^{\mathrm{b}}$ \\
\hline
\end{tabular}

${ }^{a, b}$ Values with different superscripts in the same column are significantly different $(P=0.03$ for PA and $P=0.007$ for SCNT). 

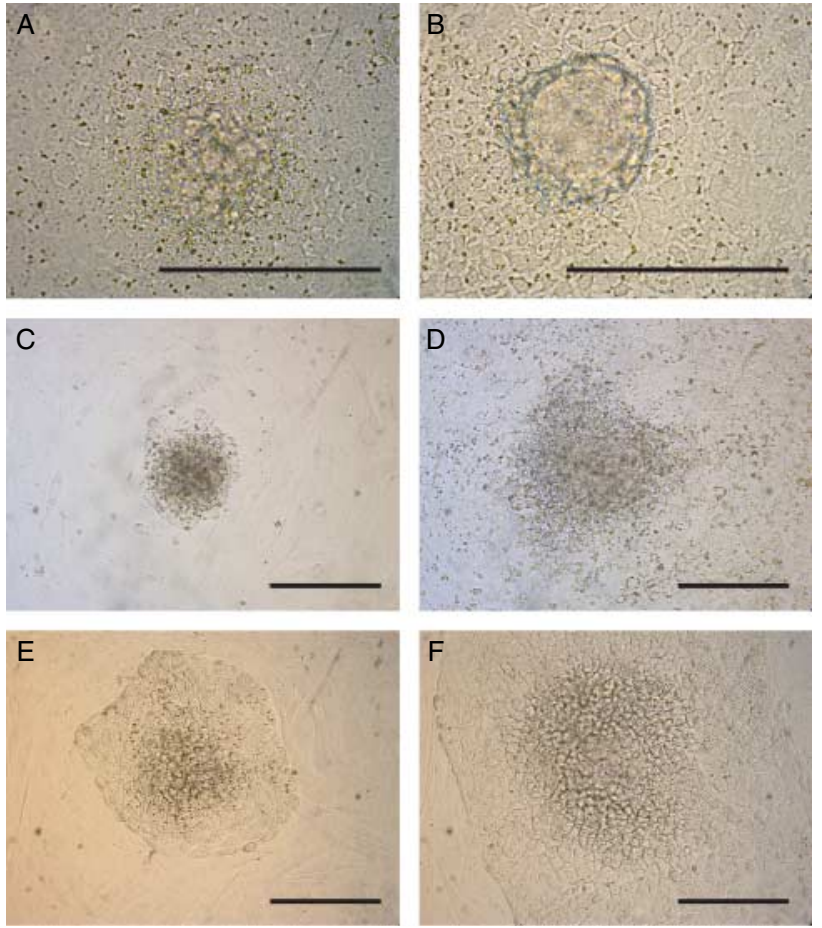

Figure 2 Formation of primary ICM outgrowths in vitro. Primary ICM outgrowths at day 1 (A, C and E) or day 5 (B, D and F) of culture, derived from in vivo (A and $\mathrm{B}), \mathrm{PA}(\mathrm{C}$ and $\mathrm{D})$ or SCNT (E and $\mathrm{F})$ blastocysts. Bars $=200 \mu \mathrm{m}$.

success has been achieved in the derivation of ESC lines from morula and 8-cell stages (Strelchenko 1996, Mitalipova et al. 2001).

Primary ICM outgrowths derived from in vivo equine embryos are composed of a compact, tightly packed mass of small cells surrounded by another cell type, presumably PE cells. This mass grows on the top of a monolayer of epithelioid cells. This morphology has been described as well for bovine primary ICM outgrowths (Talbot et al. 1995, Keefer et al. 2007), suggesting a close resemblance between equine and bovine ICM cells organisation, although the presence of an outer layer of PE is not described in other reports on equine ES-like cells (Saito et al. 2002, Li et al. 2006). In our study, the primary ICM outgrowths derived from PA and SCNT blastocysts had a different morphology than that observed for in vivo-derived primary ICM outgrowths. The PE cells covering the ICM outgrowth were more abundant, and growing as rounded and loosely attached cells on top of the ICM outgrowth. This morphology has also been described in ICM primary outgrowths from bovine PA and NT blastocysts (Kwon et al. 2009). The surrounding PE cells may be protecting the undifferentiated ICM cells from differentiationinducing factors present in the culture medium, because isolation of ICM outgrowth-derived cells for passaging and plating resulted in rapid cell differentiation. It is not yet clear in equine species whether LIF is required to maintain the undifferentiated state, as reports are not unanimous on this matter (Saito et al. 2002, Li et al. 2006). In human ESCs, LIF induces differentiation and may activate differentiation pathways such as MAPK/ERK (Humphrey et al. 2004). In large animals, it is not clear whether inhibition of MAPK/ERK pathway by PD98059 does result in maintenance of the undifferentiated state of ES-like cells (Cao et al. 2009).

The presence of the pluripotency marker genes POU5F1, SOX2 and NANOG by RT-PCR in one primary ICM outgrowth from in vivo embryo and in two from NT embryos strongly suggests the presence of undifferentiated ICM cells in these initial cultures. In addition, the high expression of NANOG in in vivo and SCNT, but not in PA, ICM outgrowths suggests that SCNT embryos have a behaviour that is similar to in vivo embryos after they have been placed in culture. The presence of TS marker genes EOMES and $C D X 2$ suggests that trophoblast is also a component of these heterogeneous cultures, even if the ICM was initially isolated. The heterogeneity of the cultures might be explained by the incomplete removal of extraembryonic cells upon ICM isolation or by the spontaneous differentiation of ICM outgrowth-derived cells into extraembryonic cells. It could also be explained by a dysregulated expression of genes as an artifact of in vitro culture, as suggested by Choi et al. (2009).

The cells that have been derived in this study from PA and SCNT primary ICM outgrowths display a high nucleus to cytoplasm ratio, and the colonies have defined borders, which are characteristics of mouse and human ESCs (Robertson 1987, Thomson et al. 1998). These cells grow in tightly packed colonies initially, as described in other reports of equine ES-like cells (Saito et al. 2002, Li et al. 2006). However, their morphology changes a few days after passage, all the while retaining AP activity. They grow either as multilayered cell clumps in the middle of flattened epithelioid cells or as flattened colonies, as it was described for bovine PA and NT-derived ES-like cells (Wang et al. 2005).

It was reported in the literature that colony morphology and AP activity are not reliable markers for identification of ES cells in large animals such as equine,

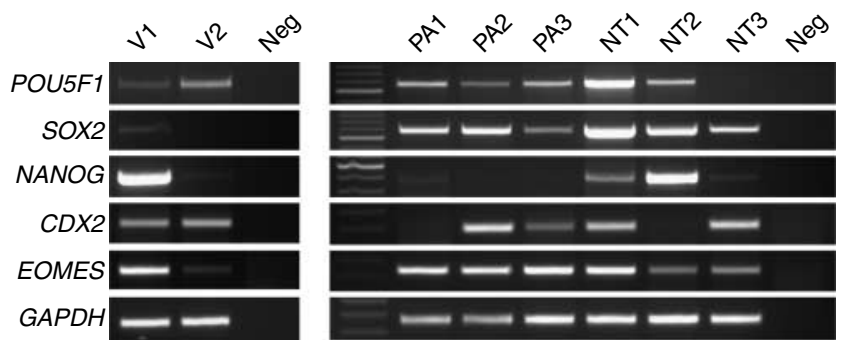

Figure 3 Molecular characterisation of primary colonies derived from equine in vivo, PA and SCNT embryos by RT-PCR. POU5F1, NANOG and SOX2 are molecular markers for pluripotent ESCs. CDX2 and EOMES are molecular markers for TS cells. GAPDH is a constitutively expressed gene and serves as a control for gene expression. 

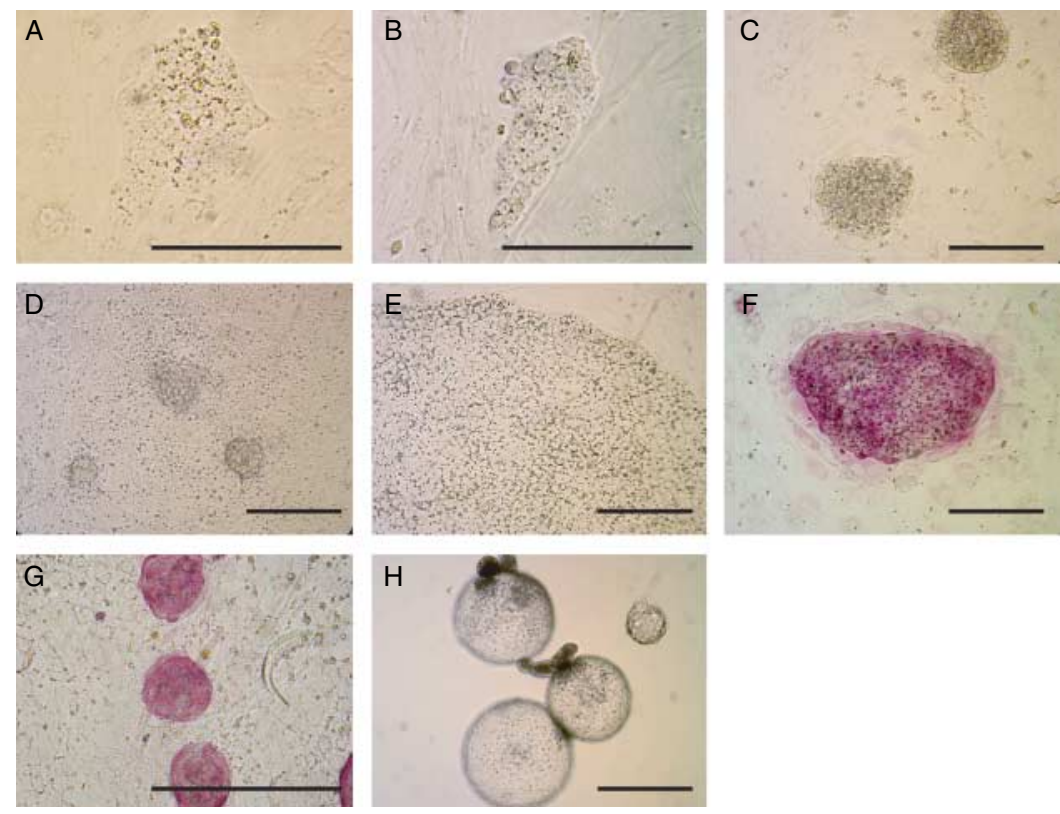

bovine and porcine species (reviewed in Keefer et al. (2007)). In bovine species, AP is expressed in the trophoblast and the epiblast of the embryo (Talbot et al. 1995, Vejlsted et al. 2005), as well as in TS cells in culture (Cao et al. 2009). In equine species, AP was reported to be almost exclusively active in the ICM of the blastocyst (Guest \& Allen 2007). This specificity of AP activity to the equine ICM may only apply to embryos in situ, since our results demonstrate the presence of AP activity in differentiated cells. Hence, together, these results suggest that the presence of AP activity and distinct morphology are not sufficient to claim obtention of ESCs.

Molecular profiling of pluripotency and extraembryonic markers as well as in vitro differentiation were therefore conducted to confirm the identity of the PA cells obtained after passaging of primary ICM outgrowths. POU5F1, SOX2, CDX2 and EOMES expression was observed in most of the cells, but NANOG was either not detected or very weak. Differentiation was induced and EB-like structures showed a cystic morphology after 7 days of culture. Appearance of cystic EB-like structures following suspension culture in differentiation-inducing medium was also reported by Saito et al. (2002) and Li et al. (2006). We conducted molecular characterisation of these cystic EB-like structures to obtain further information on their phenotype, as human EBs derived from ESCs of cystic morphology have been shown to be able to differentiate into all three germ layers as well as into extraembryonic tissues (Gerami-Naini et al. 2004). Following induction of differentiation, POU5F1, CDX2 and EOMES expression was maintained, but $S O X 2$ expression was lost. These results suggest that differentiation is directed preferentially into extraembryonic cells, positive for
POU5F1 expression. POU5F1 was also detected in EB-like aggregates from other equine ES-like cell lines (Li et al. 2006), suggesting that ES-like cells from this study are of a similar cell type to the ones described in this study. In our study, a further indication of the differentiation of cells from the primary ICM outgrowths into TS cells upon passages is their short lifespan in culture; none of the PA cells obtained after passages of primary ICM outgrowths could be maintained beyond seven passages. Altogether, these results suggest that the PA cells obtained in this study have the hallmarks of TS cells positive for the expression of POU5F1 mRNA and AP activity. To ascertain whether POU5F1 protein is expressed in equine extraembryonic tissues, immunolocalisation was conducted in in vivo, PA and SCNT embryos.

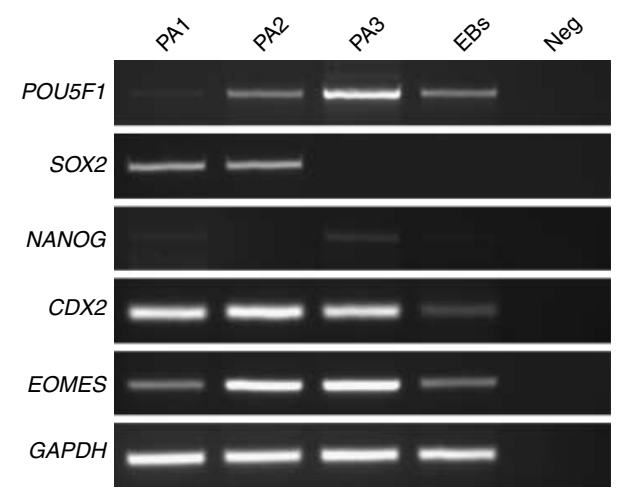

Figure 5 Molecular characterisation of equine PA cells derived from primary ICM outgrowths and of EBs by RT-PCR. POU5F1, NANOG and $S O X 2$ are molecular markers for pluripotent ESCs. CDX2 and EOMES are molecular markers for TS cells. GAPDH is a constitutively expressed gene and serves as a control for gene expression. 


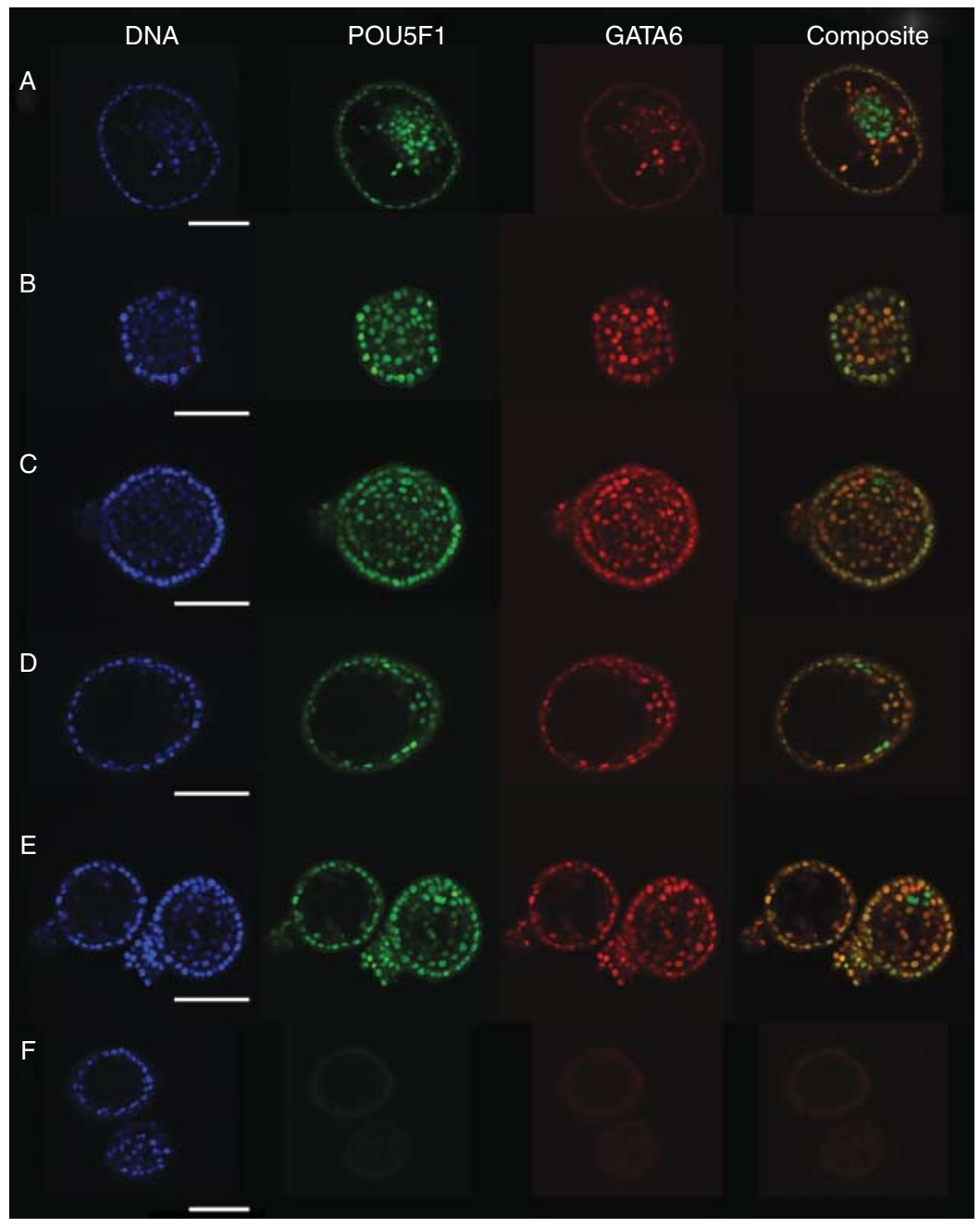

Figure 6 Immunofluorescent localisation of POU5F1 and GATA6 proteins in equine in vivo $(\mathrm{A}), \mathrm{PA}(\mathrm{B}, \mathrm{C}$ and $\mathrm{D})$ and SCNT (E) embryos. In $7.5 \mathrm{dpc}$ in vivo embryos (A), POU5F1 localises to the TE, PE and ICM, whereas GATA6 is specific to the PE. In 6.0 days postactivation PA early blastocysts (B), cells from the TE and PE are positive for both POU5F1 and GATA6. In 8.0 days post-activation PA blastocysts at early phase of expansion (C), the same pattern is observed for POU5F1 and GATA6, but a few cells are exclusively positive for POU5F1 in the ICM. In 8.0 days postactivation PA expanded blastocysts (D), POU5F1 localises to the TE, the PE as well as to the ICM, whereas GATA6 is expressed in the PE, but not in the ICM cells. In 7.5 days post-activation SCNT blastocysts (E), POU5F1 and GATA6 proteins are observed in the TE as well as in the PE, whereas the ICM cells express exclusively POU5F1. No signal is observed in PA embryos incubated with both negative control IgGs (F). Bars $=100 \mu \mathrm{m}$.
This study highlights the expression of both POU5F1 and GATA6 proteins in in vivo, PA and SCNT blastocysts. POU5F1 was found to be localised in the TE, PE as well as in the ICM of equine in vivo blastocysts. The distribution of POU5F1 was similar in equine PA and SCNT embryos. In two previous studies of the localisation of POU5F1 in equine 7 and $11 \mathrm{dpc}$ in vivo blastocysts, POU5F1 was shown to be very weak in the TE and mostly specific to the ICM (Guest \& Allen 2007, Choi et al. 2009). In our study, although POU5F1 immunofluorescence signal appears to be brighter in the ICM than in the TE in the three $7 \mathrm{dpc}$ equine blastocysts examined, we are not confident that the technique used is allowing precise quantification of the signal. The immunolocalisation studies conducted in the equine blastocyst by Choi et al. (2009) suggest that POU5F1 signal in the TE would be an artifact of culture, due to a lack of repression of its expression by the uterine environment. Our results tend to agree with these findings, since the POU5F1 signal of the TE of in vitroderived embryos seems to be brighter relatively to the signal of the ICM, in comparison with what is observed with the in vivo embryos.

In this study, GATA6 was predominantly found in the $\mathrm{PE}$, and already expressed in $7 \mathrm{dpc}$ in vivo embryos, showing that the ICM had undergone differentiation into epiblast and hypoblast at this stage. In PA and SCNT embryos, the distinction between GATA6-negative epiblast and GATA6-positive hypoblast was not clear at 7 days post-activation. This could reflect that PA and SCNT embryos develop at a slower pace in vitro, and that the signaling for pluripotency genes might be dysregulated in in vitro embryos (Choi et al. 2009). In sharp contrast in the mouse, Gata6 and Pou5f1 expression is segregated when epiblast appears in early post-implantation embryos (Chazaud et al. 2006). Interestingly, the presence of only a few ICM cells exclusively POU5F1positive in equine PA and SCNT embryos might explain in part why the primary ICM outgrowths obtained in this study were much smaller in size. On the other hand, the high number of GATA6-POU5F1 double positive cells in PA and SCNT equine embryos might explain why the 
primary ICM outgrowths derived from these embryos had a tendency to differentiate more readily into PE in vitro. The expression of POU5F1 protein in equine TE and PE indicates that POU5F1 is not a sufficient marker to identify pluripotent ESCs in this species. The presence of POU5F1,CDX2 and EOMES, but not NANOG, in the cell lines derived in this study from PA primary ICM outgrowths rather suggests that TS cell lines were derived.

Overall, this study shows that it is possible to derive primary ICM outgrowths from PA and SCNT equine embryos. Both the use of early-stage blastocysts with a clearly visible ICM and the use of pronase to dissect the ICM allow the derivation of a higher proportion of primary ICM outgrowths from these embryos. This study further indicates that markers currently used to characterise mouse and human ESCs may not be suitable to characterise equine ESCs, and that more fundamental knowledge of ICM cell biology in the equine species is required to determine the culture conditions that will allow proliferation of equine ESCs in an undifferentiated state in culture. The results presented in this study illustrate an advance in the determination of protocols for the derivation of primary equine ICM outgrowths and the characterisation of equine ICM-derived cells. It also represents an important step forward for the development of autologous equine ESC therapies in an important pre-clinical species, the horse.

\section{Materials and Methods}

\section{Animals and embryo recovery}

Procedures involving the recovery of in vivo embryos from mares were carried out following standard protocols accepted by the International Embryo Transfer Society, which are in compliance with the guidelines of the Canadian Council on Animal Care. Ovulation in mares was synchronised by injection of cloprostenol sodium (125 $\mu \mathrm{g}$ i.m., Intervet, Montreal, QC, Canada) at day 10 of the estrus cycle (day 0 is taken as the day of ovulation), followed $36 \mathrm{~h}$ later by an injection of human chorionic gonadotropin (2000 IU i.v., Intervet) and artificial insemination $12 \mathrm{~h}$ later with $500 \times 10^{6}$ progressively motile spermatozoa. Blastocysts were recovered by repeated uterine flushing between days 6 and 8 following artificial insemination, using a medium composed of tissue culture medium-199 (TCM-199), 25 mmol// HEPES (Invitrogen) and $10 \%(\mathrm{v} / \mathrm{v})$ fetal bovine serum (FBS, Invitrogen), and were transported to the laboratory in a portable incubator within $1-3 \mathrm{~h}$ from recovery.

\section{Oocyte recovery for in vitro production of embryos}

Equine ovaries were obtained from the local slaughterhouse and transported to the laboratory in sterile saline within $2 \mathrm{~h}$. Cumulus-oocyte complexes (COCs) were recovered by aspirating follicles measuring between 5 and $30 \mathrm{~mm}$ in diameter with a $18 \mathrm{G}$ needle. COCs were washed in
TCM-199 supplemented with $1 \mathrm{mg} / \mathrm{ml}$ fatty acid-free BSA (Sigma) and $5 \mu \mathrm{l} / \mathrm{ml}$ gentamicin (Sigma). Oocytes were matured for $20 \mathrm{~h}$ in vitro in a medium composed of TCM-199 supplemented with $10 \% \mathrm{FBS}, 5 \mu \mathrm{l} / \mathrm{ml}$ gentamicin, $5 \mu \mathrm{g} / \mathrm{ml} \mathrm{LH}$ (Bioniche, Belleville, ON, Canada), $1 \mu \mathrm{g} / \mathrm{ml}$ FSH (Folltropin-V, Bioniche), $50 \mathrm{ng} / \mathrm{ml}$ epidermal growth factor (Sigma) and $100 \mathrm{ng} / \mathrm{ml}$ insulin-like growth factor 1 (Invitrogen). To remove cumulus cells, COCs were pipetted in TCM-199 containing $25 \mathrm{mmol} / \mathrm{l}$ HEPES, $10 \%$ FBS and $400 \mathrm{U} / \mathrm{ml}$ hyaluronidase (Sigma) for 2-5 min. Oocytes displaying a homogeneous cytoplasm were selected for NT.

\section{Nuclear transfer}

Fibroblast donor cells were isolated from skin biopsies taken from an adult horse. Isolation and culture of fibroblasts was carried out using $0.01 \%(\mathrm{w} / \mathrm{v})$ collagenase I (Sigma), as described in the 'Derivation of feeder cell lines' section. Fibroblasts were cultured for 3-5 passages and frozen. Thawed fibroblasts were used for NT between passages 3 and 5 . For NT, a single fibroblast donor cell was placed into the perivitelline space of an enucleated oocyte using a micromanipulator. The ooplasm-fibroblast couplets were transferred in fusion buffer $\left(0.3 \mathrm{~mol} / \mathrm{l}\right.$ mannitol, $50 \mu \mathrm{mol} / \mathrm{l} \mathrm{CaCl}_{2}$ and $100 \mu \mathrm{mol} / / \mathrm{MgCl}_{2}$, all from Sigma) to a fusion chamber and exposed to a double direct current pulse of $1.5 \mathrm{KV} / \mathrm{cm}$ for $30 \mu \mathrm{s}$. Activation of fused couplets was induced by injection of stallion sperm extract prepared according to Choi et al. (2002), followed by $4 \mathrm{~min}$ treatment with $8.5 \mu \mathrm{mol} / \mathrm{l}$ ionomycin (Sigma). Reconstructed embryos were then incubated for $3 \mathrm{~h}$ in $2 \mathrm{mM}$ 6-dimethylaminopurine (6-DMAP, Sigma), washed and cultured in drops of DMEM:nutrient mixture F-12 (DMEM/ F-12) containing $10 \%$ FBS under mineral oil at $38.6{ }^{\circ} \mathrm{C}$ in an atmosphere of $5 \% \mathrm{CO}_{2}, 5 \% \mathrm{O}_{2}$ and $90 \% \mathrm{~N}_{2}$ for $6-11$ days. At day 5 of culture, fresh medium was added to each drop.

\section{Parthenogenetic activation}

To produce PA equine embryos, denuded oocytes were selected for the presence of a polar body and activated with $5 \mu \mathrm{M}$ ionomycin for $4 \mathrm{~min}$, then incubated $3 \mathrm{~h}$ in $2 \mathrm{mmol} / \mathrm{l}$ 6-DMAP. Activated oocytes were cultured in DMEM/F-12 containing $10 \%$ FBS for $6-11$ days as described for the NT embryos.

\section{Derivation of feeder cell lines}

An equine foetus from the first trimester of gestation was collected at the local slaughterhouse and carried to the laboratory in sterile saline. Fragments of skin and muscle were dissected into small pieces using a scalpel blade, and fibroblasts were isolated according to the method described in Yoo et al. (2007).

Equine and bovine umbilical cords were collected from newborns at the time of parturition. The Wharton's jelly was dissected and washed in PBS with antibiotics $(100 \mathrm{IU} / \mathrm{ml}$ penicillin and $100 \mu \mathrm{g} / \mathrm{ml}$ streptomycin, Invitrogen). The Wharton's jelly was dissociated into small pieces using scissors and digested with $0.01 \%(\mathrm{w} / \mathrm{v})$ collagenase I at $37^{\circ} \mathrm{C}$ for $3 \mathrm{~h}$. 
Dislodged cells were resuspended by pipetting and placed in a $15 \mathrm{ml}$ tube. Cell suspension was centrifuged at $200 \mathrm{~g}$ for $10 \mathrm{~min}$. The pellet was resuspended in feeder cell medium, filtered to eliminate cell clumps and plated into T25 culture flasks. Feeder cells were mitotically inactivated with mitomycin C $(10 \mu \mathrm{g} / \mathrm{ml}$, Sigma) for $3 \mathrm{~h}$, dissociated with $0.25 \%(\mathrm{w} / \mathrm{v})$ trypsin-0.01\% (w/v) EDTA (Invitrogen) and plated at a density of 100000 cells $/ \mathrm{ml}$ in four-well plates (Nalge Nunc International, Naperville, IL, USA), pre-treated with a solution of $0.1 \%(\mathrm{w} / \mathrm{v})$ gelatin (Sigma). Fibroblasts were maintained in an atmosphere of $5 \% \mathrm{CO}_{2}$, at $38.6{ }^{\circ} \mathrm{C}$.

\section{Embryo culture and formation of primary ICM outgrowths}

Zonae pellucidae were removed using $10 \mathrm{mg} / \mathrm{ml}$ pronase (Sigma). Embryos were classified according to their age, developmental stage and appearance of their ICM, and were subjected to different protocols for ICM isolation. In the trypsin protocol, in vivo, PA and SCNT embryos were placed in $0.25 \%$ trypsin-EDTA for about $15 \mathrm{~min}$, until trophoblast cells began to dissociate. Embryos were pipetted several times to dislodge trophoblast cells from the blastocyst. In the pronase protocol, PA and SCNT blastocysts were incubated with $10 \mathrm{mg} / \mathrm{ml}$ pronase for 5-30 min, until trophoblast cells began to dissociate. Isolated ICMs were placed in culture on BUCF, EUCF or EEF feeder cells, 24-48 h after mitotic inactivation. Equine ICMs were cultured in equine ESC medium consisting of $85 \%$ DMEM-knockout/F-12 (Invitrogen), 15\% FBS (HyClone, Logan, UT, USA), $0.1 \mathrm{mmol} / \mathrm{l} 2$ 2-mercaptoethanol (Sigma), 1\% (w/v) non-essential amino acids, $200 \mu \mathrm{mol} / \mathrm{l}$ L-glutamine, $1 \mathrm{mmol} / \mathrm{l}$ sodium pyruvate (Invitrogen) and $0.04 \mu \mathrm{g} / \mathrm{ml}$ human LIF (Chemicon International, Temecula, CA USA). Medium was changed every day, except for the first $48 \mathrm{~h}$ of culture. Equine PA and SCNT cell lines derived from primary ICM outgrowths were maintained in an atmosphere of $5 \% \mathrm{CO}_{2}$, at $38.6{ }^{\circ} \mathrm{C}$.

To passage cells, the primary ICM outgrowth was cut using a scalpel under a stereomicroscope. Collagenase IV $(1 \mathrm{mg} / \mathrm{ml}$ in DMEM-KO/F-12, Invitrogen) was used to dislodge the selected part of the colony, and the cell clump was placed in $0.25 \%$ trypsin-EDTA a few seconds to allow partial dissociation into smaller clumps. Clumps were washed in equine ESC culture medium when possible or placed directly in a well with a new feeder layer. EEFs were used to culture PA cell lines. To induce differentiation, dissociated cells were cultured for 7 days in suspension without feeder cells or LIF.

\section{Molecular and biochemical characterisation}

AP activity was detected using the AP detection kit (Chemicon International) according to the manufacturer's instructions. Total RNA was purified using the Qiagen micro RNA isolation kit (Qiagen), according to the manufacturer's instructions. DNase I (Invitrogen) treatment was performed once during the purification and once during the RT protocol. RT was performed using Superscript II (Invitrogen) as recommended by the manufacturer. For all samples, a negative RT was used as a control, consisting of an RT reaction omitting the reverse transcriptase. In addition, PCR omitting the cDNA was used as a negative control. All primers were designed to span at least two exons. The following primers and annealing temperatures (Ta) were used: POU5F1: forward 5'-TCCCAGGACATCAAAGCTCTGCAGA-3', reverse 5'-TCAGTTTGAATGCATGGGAGAAGCCCAGA-3', Ta $=57^{\circ} \mathrm{C} ; \quad$ NANOG: forward 5'-GACAGCCCCGATTCATCCACCAG-3', reverse 5'-GCACCAGGTCTGACTGTTCCAGG- $3^{\prime}, \mathrm{Ta}=57^{\circ} \mathrm{C}$; SOX2: forward $5^{\prime}$-GGC GGC AAC CAG AAG AAC AG-3', reverse $5^{\prime}$-AGA AGA GGT AAC CAC GGG GG- $3^{\prime}, \mathrm{Ta}=57^{\circ} \mathrm{C}$; glyceraldehyde 3-phosphate dehydrogenase $(G A P D H)$ : forward $5^{\prime}$-GTCCATGCCATCACTGCCAC-3', reverse 5'-CCTGCTTCACCACCTTCTTG-3', Ta $=55^{\circ} \mathrm{C}$; EOMES: forward 5'-CCACCGCCACCAAACTGAGATG- $3^{\prime}$, reverse $5^{\prime}$-CAGTATTAGGAGACTCTGGGTGAA- $3^{\prime}, \quad \mathrm{Ta}=57^{\circ} \mathrm{C}$; and $C D X 2$ : forward $5^{\prime}$-CAGCCAAGTGAAAACCAGGACGA-3', reverse $5^{\prime}$-CCTCTCCTTTGCTCTGCGGTTC $-3^{\prime}, \mathrm{Ta}=57^{\circ} \mathrm{C}$.

\section{Immunofluorescence}

Three in vivo embryos, ten PA embryos and three SCNT embryos without zonae pellucidae were fixed with $-20^{\circ} \mathrm{C}$ methanol and then stored at $-20^{\circ} \mathrm{C}$ until immunofluorescence staining. Embryos were washed once in 50\% (v/v) methanol/PBS and three times for $5 \mathrm{~min}$ in PBS. Blocking was performed by incubating the embryos for $15 \mathrm{~min}$ in blocking solution (10\% PBS-Tween-20 (PBST) and 10\% normal goat serum). Double-labelling immunofluorescence was carried out overnight at $4{ }^{\circ} \mathrm{C}$ in a humid chamber using a cocktail of POU5F1 (C-10) mouse MAB (Santa Cruz, Santa Cruz, CA, USA, sc-5279) specific to isoform POU5F1A 1:50 (4 $\mu \mathrm{g} / \mathrm{ml})$ and GATA6 rabbit polyclonal antibody (Santa Cruz, H-92) 1:50 $(4 \mu \mathrm{g} / \mathrm{ml})$. As a control, a cocktail of mouse $\lg _{2 b}$ antibody $1: 25$ $(4 \mu \mathrm{g} / \mathrm{ml})$ and rabbit IgG antibody $1: 500(4 \mu \mathrm{g} / \mathrm{ml}, \mathrm{R} \& \mathrm{D}$ systems, Minneapolis, MN, USA) was used. Primary antibodies were washed three times for $5 \mathrm{~min}$ in PBST. This was followed by a $1 \mathrm{~h}$ incubation with a cocktail of secondary antibody prepared with anti-mouse Alexa Fluor 488 and anti-rabbit Alexa Fluor 594 (Invitrogen) both at 1:1000 concentration. All antibodies and control isotypes were diluted in the blocking solution. Blastocysts and outgrowths were washed three times in PBST and placed in the SlowFade Gold mounting medium containing 4',6-diamidino-2-phenylindole (Invitrogen). Representative embryos of each group are shown in Fig. 6.

\section{Statistical analyses}

The $\chi^{2}$ test was used to determine statistical differences between experimental groups. Statistical analyses were performed with the JMP program (SAS Institute, Cary, NJ, USA), and a probability level of $P<0.05$ was considered significant.

\section{Declaration of interest}

The authors declare that there is no conflict of interest that could be perceived as prejudicing the impartiality of the research reported. 


\section{Funding}

Financial support for this study was provided by the Canadian Arthritis Network (S Laverty and L C Smith). J A Desmarais is a recipient of a Postdoctoral Trainee Fellowship Award from the Canadian Arthritis Network and Clonagen Inc.

\section{Acknowledgements}

The authors acknowledge the excellent technical support from $S$ Benmouissa and C Léveillée, the constructive comments on the manuscript from $\mathrm{T}$ Tuuri and the contribution of Clonagen Inc., St-Hyacinthe, Quebec, Canada.

\section{References}

Allen ND, Barton SC, Hilton K, Norris ML \& Surani MA 1994 A functional analysis of imprinting in parthenogenetic embryonic stem cells. Development 120 1473-1482.

Balakier H \& Tarkowski AK 1976 Diploid parthenogenetic mouse embryos produced by heat-shock and cytochalasin B. Journal of Embryology and Experimental Morphology 35 25-39.

Brambrink T, Hochedlinger K, Bell G \& Jaenisch R 2006 ES cells derived from cloned and fertilized blastocysts are transcriptionally and functionally indistinguishable. PNAS 103 933-938. (doi:10.1073/pnas. 0510485103)

Cao S, Wang F, Chen Z, Liu Z, Mei C, Wu H, Huang J, Li C, Zhou L \& Liu L 2009 Isolation and culture of primary bovine embryonic stem cell colonies by a novel method. Journal of Experimental Zoology. Part A, Ecological Genetics and Physiology 311 368-376. (doi:10.1002/jez.535)

Chazaud C, Yamanaka Y, Pawson T \& Rossant J 2006 Early lineage segregation between epiblast and primitive endoderm in mouse blastocysts through the Grb2-MAPK pathway. Developmental Cell 10 615-624. (doi:10.1016/j.devcel.2006.02.020)

Chen LR, Shiue YL, Bertolini L, Medrano JF, BonDurant RH \& Anderson GB 1999 Establishment of pluripotent cell lines from porcine preimplantation embryos. Theriogenology 52 195-212. (doi:10.1016/S0093-691X(99) 00122-3)

Choi YH, Love CC, Chung YG, Varner DD, Westhusin ME, Burghardt RC \& Hinrichs K 2002 Production of nuclear transfer horse embryos by Piezodriven injection of somatic cell nuclei and activation with stallion sperm cytosolic extract. Biology of Reproduction 67 561-567. (doi:10.1095/ biolreprod67.2.561)

Choi YH, Harding HD, Hartman DL, Obermiller AD, Kurosaka S, McLaughlin KJ \& Hinrichs K 2009 The uterine environment modulates trophectodermal POU5F1 levels in equine blastocysts. Reproduction 138 589-599. (doi:10.1530/REP-08-0394)

Cibelli JB, Stice SL, Golueke PJ, Kane JJ, Jerry J, Blackwell C, Ponce de Leon FA \& Robl JM 1998 Transgenic bovine chimeric offspring produced from somatic cell-derived stem-like cells. Nature Biotechnology 16 642-646. (doi:10.1038/nbt0798-642)

Cibelli JB, Grant KA, Chapman KB, Cunniff K, Worst T, Green HL, Walker SJ, Gutin PH, Vilner L, Tabar V et al. 2002 Parthenogenetic stem cells in nonhuman primates. Science 295 819. (doi:10.1126/science. 1065637)

Evans MJ, Notarianni E, Laurie S \& Moor RM 1990 Derivation and preliminary characterization of pluripotent cell lines from porcine and bovine blastocysts. Theriogenology 33 125-128. (doi:10.1016/0093691X(90)90603-Q)

Gerami-Naini B, Dovzhenko OV, Durning M, Wegner FH, Thomson JA \& Golos TG 2004 Trophoblast differentiation in embryoid bodies derived from human embryonic stem cells. Endocrinology 145 1517-1524. (doi:10.1210/en.2003-1241)

Guest DJ \& Allen WR 2007 Expression of cell-surface antigens and embryonic stem cell pluripotency genes in equine blastocysts. Stem Cells and Development 16 789-796. (doi:10.1089/scd.2007.0032)
Hochedlinger K \& Jaenisch R 2002 Monoclonal mice generated by nuclear transfer from mature B and T donor cells. Nature 415 1035-1038. (doi:10.1038/nature718)

Hochedlinger K \& Jaenisch R 2003 Nuclear transplantation, embryonic stem cells, and the potential for cell therapy. New England Journal of Medicine 349 275-286. (doi:10.1056/NEJMra035397)

Hochereau-de Reviers MT \& Perreau C 1993 In vitro culture of embryonic disc cells from porcine blastocysts. Reproduction, Nutrition, Development 33 475-483. (doi:10.1051/rnd:19930508)

Humphrey RK, Beattie GM, Lopez AD, Bucay N, King CC, Firpo MT, Rose-John S \& Hayek A 2004 Maintenance of pluripotency in human embryonic stem cells is STAT3 independent. Stem Cells 22 522-530. (doi:10.1634/stemcells.22-4-522)

Iwasaki S, Campbell KH, Galli C \& Akiyama K 2000 Production of live calves derived from embryonic stem-like cells aggregated with tetraploid embryos. Biology of Reproduction 62 470-475. (doi:10.1095/biolreprod62.2.470)

Kaufman MH, Robertson EJ, Handyside AH \& Evans MJ 1983 Establishment of pluripotential cell lines from haploid mouse embryos. Journal of Embryology and Experimental Morphology 73 249-261.

Kawase E, Yamazaki Y, Yagi T, Yanagimachi R \& Pedersen RA 2000 Mouse embryonic stem (ES) cell lines established from neuronal cell-derived cloned blastocysts. Genesis 28 156-163. (doi:10.1002/1526-968X(200011/12) 28:3/4<156::AID-GENE100>3.0.CO;2-T)

Keefer CL, Pant D, Blomberg L \& Talbot NC 2007 Challenges and prospects for the establishment of embryonic stem cell lines of domesticated ungulates. Animal Reproduction Science 98 147-168. (doi:10.1016/j. anireprosci.2006.10.009)

Kim K, Lerou P, Yabuuchi A, Lengerke C, Ng K, West J, Kirby A, Daly MJ \& Daley GQ 2007a Histocompatible embryonic stem cells by parthenogenesis. Science 315 482-486. (doi:10.1126/science.1133542)

Kim K, Ng K, Rugg-Gunn PJ, Shieh JH, Kirak O, Jaenisch R, Wakayama T, Moore MA, Pedersen RA \& Daley GQ 2007b Recombination signatures distinguish embryonic stem cells derived by parthenogenesis and somatic cell nuclear transfer. Cell Stem Cell 1 346-352. (doi:10.1016/ j.stem.2007.07.001)

Kwon DK, Hong SG, Park HJ, Kang JT, Koo OJ \& Lee BC 2009 Epiblast isolation by a new four stage method (peeling) from whole bovine cloned blastocysts. Cell Biology International 33 309-317. (doi:10.1016/j. cellbi.2008.12.003)

Lanza RP, Chung HY, Yoo JJ, Wettstein PJ, Blackwell C, Borson N, Hofmeister E, Schuch G, Soker S, Moraes CT et al. 2002 Generation of histocompatible tissues using nuclear transplantation. Nature Biotechnology 20 689-696. (doi:10.1038/nbt703)

Li M, Zhang D, Hou Y, Jiao L, Zheng X \& Wang WH 2003 Isolation and culture of embryonic stem cells from porcine blastocysts. Molecular Reproduction and Development 65 429-434. (doi:10.1002/mrd.10301)

Li M, Li YH, Hou Y, Sun XF, Sun Q \& Wang WH 2004a Isolation and culture of pluripotent cells from in vitro produced porcine embryos. Zygote 12 43-48. (doi:10.1017/S0967199404002679)

Li M, Ma W, Hou Y, Sun XF, Sun QY \& Wang WH $2004 b$ Improved isolation and culture of embryonic stem cells from Chinese miniature pig. Journal of Reproduction and Development 50 237-244. (doi:10.1262/ jrd.50.237)

Li X, Zhou SG, Imreh MP, Ahrlund-Richter L \& Allen WR 2006 Horse embryonic stem cell lines from the proliferation of inner cell mass cells. Stem Cells and Development 15 523-531. (doi:10.1089/scd.2006. 15.523)

Lin H, Lei J, Wininger D, Nguyen MT, Khanna R, Hartmann C, Yan WL \& Huang SC 2003 Multilineage potential of homozygous stem cells derived from metaphase II oocytes. Stem Cells 21 152-161. (doi:10.1634/ stemcells.21-2-152)

Mitalipova M, Beyhan Z \& First NL 2001 Pluripotency of bovine embryonic cell line derived from precompacting embryos. Cloning 3 59-67. (doi:10.1089/15204550152475563)

Munsie MJ, Michalska AE, O'Brien CM, Trounson AO, Pera MF \& Mountford PS 2000 Isolation of pluripotent embryonic stem cells from reprogrammed adult mouse somatic cell nuclei. Current Biology 10 989-992. (doi:10.1016/S0960-9822(00)00648-5)

Notarianni E, Laurie S, Moor RM \& Evans MJ 1990 Maintenance and differentiation in culture of pluripotential embryonic cell lines from pig blastocysts. Journal of Reproduction and Fertility. Supplement 41 51-56. 
Ohgane J, Wakayama T, Kogo Y, Senda S, Hattori N, Tanaka S, Yanagimachi R \& Shiota K 2001 DNA methylation variation in cloned mice. Genesis 30 45-50. (doi:10.1002/gene.1031)

Piedrahita JA, Anderson GB \& Bondurant RH 1990 Influence of feeder layer type on the efficiency of isolation of porcine embryo-derived cell lines. Theriogenology 34 865-877. (doi:10.1016/0093-691X(90)90558-B)

Rideout WM III, Hochedlinger K, Kyba M, Daley GQ \& Jaenisch R 2002 Correction of a genetic defect by nuclear transplantation and combined cell and gene therapy. Cell 109 17-27. (doi:10.1016/S0092-8674(02) 00681-5)

Robertson E 1987 Embryo-derived stem cell lines. In Teratocarcinomas and Embryonic Stem Cells: A Practical Approach, 1st edn, pp 71-112. Oxford, UK: IRL Press.

Saito S, Ugai H, Sawai K, Yamamoto Y, Minamihashi A, Kurosaka K, Kobayashi Y, Murata T, Obata Y \& Yokoyama K 2002 Isolation of embryonic stem-like cells from equine blastocysts and their differentiation in vitro. FEBS Letters 531 389-396. (doi:10.1016/S0014-5793(02) 03550-0)

Saito S, Sawai K, Ugai H, Moriyasu S, Minamihashi A, Yamamoto Y, Hirayama H, Kageyama S, Pan J, Murata T et al. 2003 Generation of cloned calves and transgenic chimeric embryos from bovine embryonic stem-like cells. Biochemical and Biophysical Research Communications 309 104-113. (doi:10.1016/S0006-291X(03)01536-5)

Sims M \& First NL 1994 Production of calves by transfer of nuclei from cultured inner cell mass cells. PNAS 91 6143-6147. (doi:10.1073/pnas. 91.13.6143)

Singh U, Fohn LE, Wakayama T, Ohgane J, Steinhoff C, Lipkowitz B, Schulz R, Orth A, Ropers HH, Behringer RR et al. 2004 Different molecular mechanisms underlie placental overgrowth phenotypes caused by interspecies hybridization, cloning, and Esx1 mutation. Developmental Dynamics 230 149-164. (doi:10.1002/dvdy.20024)

Strelchenko N 1996 Bovine pluripotent stem cells. Theriogenology 45 131-140. (doi:10.1016/0093-691X(95)00362-C)

Surani MA \& Barton SC 1983 Development of gynogenetic eggs in the mouse: implications for parthenogenetic embryos. Science 222 1034-1036. (doi:10.1126/science.6648518)

Talbot NC, Powell AM \& Rexroad CE Jr 1995 In vitro pluripotency of epiblasts derived from bovine blastocysts. Molecular Reproduction and Development 42 35-52. (doi:10.1002/mrd.1080420106)

Talbot NC, Caperna TJ, Powell AM, Ealy AD, Blomberg LA \& Garrett WM 2005 Isolation and characterization of a bovine visceral endoderm cell line derived from a parthenogenetic blastocyst. In Vitro Cellular \& Developmental Biology. Animal 41 130-141. (doi:10.1290/040901.1)
Theoret CL, Dore M, Mulon PY, Desrochers A, Viramontes F, Filion F \& Smith LC 2006 Short- and long-term skin graft survival in cattle clones with different mitochondrial haplotypes. Theriogenology 65 1465-1479. (doi:10.1016/j.theriogenology.2005.08.019)

Thomson JA, Itskovitz-Eldor J, Shapiro SS, Waknitz MA, Swiergiel JJ, Marshall VS \& Jones JM 1998 Embryonic stem cell lines derived from human blastocysts. Science 282 1145-1147. (doi:10.1126/science.282. 5391.1145)

Vejlsted M, Avery B, Schmidt M, Greve T, Alexopoulos N \& MaddoxHyttel P 2005 Ultrastructural and immunohistochemical characterization of the bovine epiblast. Biology of Reproduction 72 678-686. (doi:10.1095/biolreprod.104.034348)

Wakayama T, Tabar V, Rodriguez I, Perry AC, Studer L \& Mombaerts P 2001 Differentiation of embryonic stem cell lines generated from adult somatic cells by nuclear transfer. Science 292 740-743. (doi:10.1126/science. 1059399)

Wakayama S, Jakt ML, Suzuki M, Araki R, Hikichi T, Kishigami S, Ohta H, Van Thuan N, Mizutani E, Sakaide Y et al. 2006 Equivalency of nuclear transfer-derived embryonic stem cells to those derived from fertilized mouse blastocysts. Stem Cells 24 2023-2033. (doi:10.1634/stemcells. 2005-0537)

Wang L, Duan E, Sung LY, Jeong BS, Yang X \& Tian XC 2005 Generation and characterization of pluripotent stem cells from cloned bovine embryos. Biology of Reproduction 73 149-155. (doi:10.1095/biolreprod.104. 037150)

Wang S, Tang X, Niu Y, Chen H, Li B, Li T, Zhang X, Hu Z, Zhou Q \& Ji W 2007 Generation and characterization of rabbit embryonic stem cells. Stem Cells 25 481-489. (doi:10.1634/stemcells.2006-0226)

Wheeler MB 1994 Development and validation of swine embryonic stem cells: a review. Reproduction, Fertility, and Development 6 563-568. (doi:10.1071/RD9940563)

Yoo JG, Demers SP, Lian L \& Smith LC 2007 Developmental arrest and cytoskeletal anomalies of rat embryos reconstructed by somatic cell nuclear transfer. Cloning and Stem Cells 9 382-393. (doi:10.1089/clo. 2006.0081)

Received 30 November 2009

First decision 22 December 2009

Revised manuscript received 15 December 2010

Accepted 5 January 2011 